\title{
Teaching
Anthropology
}

2022, Vol. 11, No. 2, pp.122-128.

Developing Teaching: Reports and Reflections

\section{How to Take Over and Revise a Medical Ethnology Course in the Post- Everything Era}

\author{
Rachel Irwin \\ Lund University
}

\begin{abstract}
:
Nearly all university lecturers have taken over a course from colleagues. Yet the conceptual and practical challenges of this process are rarely discussed in higher education. In this article, I describe my experiences of becoming the course convenor of an existing medical ethnology course and revising it. The first challenge was to make the course my own, while also maintaining the existing positive aspects. A secondary, but related, challenge was to update the course material in relation to contemporary social movements that have called for more attention to power, privilege and inclusivity in the classroom.
\end{abstract}

Keywords: Pedagogy, ethnology, anthropology, medical, decolonizing, neoliberal

\section{Introduction}

Nearly all university lecturers have taken over a course from colleagues, often at short notice. This task presents a series of overlapping practical and conceptual challenges, from preparing lectures and updating syllabi, to finding the narrative coherence in the course material and structure. In the German and Scandinavian languages, this sense of coherence is often referred to as the "red thread," or röda träden in Swedish. In the pedagogical context, it refers to a narrative progression through the course, similar to the German leitmotiv. Each lecture or session should build upon the previous one, and there should be a sense that the course is coherently structured, held together by a unifying set of themes. The pedagogical goal is like well-planned smörgåsbord, in which one progresses logically through the dishes and the flavours complement each other. A course should not be a potluck, presenting a set of discrete and disparate topics.

In this article, I describe my experiences of taking over a Swedish medical ethnology course from two colleagues in the Autumn of 2020 and later revising it in 2021 and early 2022. Ultimately, the challenge was to take an existing course and make it 'my own', without making so many changes that it would be a new course, as this would require far too many administrative hurdles. Part of making a course one's own is ego-driven. While I avoided filling the reading list with my publications, I wanted to highlight my areas of expertise and teach concepts and examples with which I was familiar. This is in contrast to the first two years, in which I uncomfortably tried to teach my former colleagues' research. Additionally, in consideration to the red thread, I also wanted to enable future colleagues to take over the course from me.

Aside from this immediate task, there was a need to update the course material, including lectures and literature. This included a general update, such as taking out outdated or hard-to-find readings. It also required revisions related to the various social movements that characterised the 2010s and the related conversations about power and privilege, including \#MeToo, Black Lives Matter, decolonising the classroom and generally fostering inclusivity and accessibility (Primiano et al 2020).

In the next section, I discuss the general challenges of course revision in the neoliberal university. I then address the conceptual basis behind what I saw as deficits in the course: a need for more attention to social movements and for increased consideration of ethnographic methods. With this conceptual basis in mind, I then describe the course and my processes for making changes, touching upon the syllabus, lectures and the reading list. While I use a specific course as a case study, much of what I describe is applicable to revising any course and I have provided a template for this in Appendix 1. 


\section{Teaching Anthropology and Ethnology in the Neoliberal University}

\section{Course Revision in a Neoliberal Setting}

Much of the medical ethnology course focusses on how neoliberalism has changed health policy and practice, often negatively. With this background, I cannot help but be critical of current theories, perspectives and trends in teaching and learning, which are also characterised by neoliberal thinking (Stefanelli 2017; Krause-Jensen and Garsten 2014; Posecznick 2014). As part of this, universities are run with modalities from the private sector, particularly those relating to efficiency and cost savings. Teachers are often expected to be more 'efficient' in their teaching, which in practice means they must 'produce' more teaching materials with less time. The neoliberal turn is also characterised by increased focus on evaluation and audit, again treating education, and even individual teachers, as a 'product' to be ranked and rated. Many of these modalities have been encoded into practice and policy, in both the European and Swedish contexts (Loughlin et al 2021; Abraham 2017).

Practically, I see two - often related - course design challenges related to the neoliberal university. Because of the ubiquity of short-term contracts, a lecturer may only teach a course once or twice before moving to a different institution. Eventually this creates a disorganised course in which multiple lecturers have made incongruous changes over time. In practice the red thread becomes lost. In other cases, the course materials and reading lists can be highly dependent on the research interests of one or two lecturers; this makes it incredibly difficult for a new lecturer or course convenor to take over or join the course. Related to this, because of the way teaching is reimbursed new lecturers often have few - if any - hours for planning lectures or considering course design; there is little incentive for a lecturer on an insecure contract to 'invest' in making changes.

The neoliberal university tends to view students as consumers. In this case, teaching and learning activities are directed at improving student learning and, in turn, student evaluations. However, the lecturer should also have a meaningful classroom experience. If the lecturer has the time and institutional support to revise a course, it can increase their enthusiasm in the classroom which, in turn, should improve student learning. Even if a university refuses to give a lecturer the resources for course revision, the lecturer's experience will likely be better if they make revisions in spite of this lack of resources.

\section{The Specific Challenge: Addressing Social Movements in the Classroom}

The late 2010s and early 2020s has seen increasing calls for 'decolonialising the classroom,' which build upon much earlier work (Cheang and Suterwalla 2020; see also the Special Issue: Decolonizing Anthropology in Teaching Anthropology 2021, 10 (4)). Although there is not full agreement on what this means in practice, it is broadly about "centering perspectives and voices from marginalized populations" and "addressing and dismantling the harmful legacies of colonial and imperial powers" (Primiano et al 2020, in reference to Zembylas 2019).

However, decolonisation is neither a metaphor nor a theoretical concept, but a real ongoing struggle in many parts of the world today: in struggles for land rights, sovereignty and the environment, including parts of northern Sweden that are included in Sápmi (Barnett-Naghshineh and Pattabu 2021; Tuck and Yang 2012; Diallo and Friborg 2021). In this sense, calls for decolonising the classroom could be considered somewhat meaningless or even harmful (Tuck and Yang 2012). Tuck and Yang claim a classroom is not a place that can be decolonised, and such usage can detract attention from the need to restore sovereignty to displaced peoples. But, as I will discuss, I am inspired by discussions around decolonising the classroom, as well as from social movements such as \#MeToo and Black Lives Matters. I also draw upon the long tradition of critical medical anthropology, often focused on social justice through a Marxist lens.

From these perspectives, the task is not simply about adding non-white authors or lifting up other marginalised voices, although this is a key aspect. Rather it is about a wider approach to learning, which involves the critique of power at all levels of society. This is something already reflected in the course, which was originally designed to analyse and critique power in the health system and society at large. We also already address the relationship between knowledge and power, not least how different types of information, evidence and experiences are valued more highly in medical research and practice. However, as I discuss later, there was still room for improvement, particularly with regard to the reading list. 
There is also a disciplinary aspect tied to conversations around power and privilege. Research in ethnology and anthropology revolves around ethnographic methods. The myth of the 'traditional' white, male, able-bodied ethnographer going out to the field persists and there is a need to understand how ethnographers outside of this stereotype plan and experience fieldwork (Montesi and Johansson 2021; Tentomas 2021; Toress and Shandy 2019). Methodological discussions must also recognise how anthropology, at least historically, "depended on colonial relations for much of its knowledge production and continues to be primarily rooted in doing research 'elsewhere' outside of the Global North" (Barnett-Naghshineh and Pattabu 2021). Practically, this means using the ethnographies assigned in class to analyse the ethics and power relations inherent in research. There is also a need to 'de-romance' fieldwork and to be honest about the everyday challenges of conducting ethnographic research, from sickness to bullying to sexual assault (Montesis and Johansson 2021; Torres and Shandy 2019). I wanted to add these considerations to the literature and classroom discussions.

\section{How to Revise a Course}

The course - Health, Power and Culture- is an undergraduate ethnology course, with a focus on power, norms, health and healthcare in Swedish society. The course is 15 credits in the European Credit Transfer System (ECTS), roughly equivalent to 6 credits in the North American system. It was further divided into two subcourses: (1) Cultural analytical perspectives on power and health and (2) Encounters, Identity, Body.

Although it was missing a red thread, there were many positive aspects of the course when I became the convenor. As mentioned, it took on current issues of power and identity in healthcare, which naturally led to discussions around norms, social criticism, intersectionality, privilege and discrimination. As part of this, it also explicitly covered how neoliberal reforms to health systems affect patient experiences. While the course already focused on identity and power, and was a natural space for discussing ethnocentrism, after the 2021 autumn semester, student expressed a desire for including more diverse perspectives on the reading list, including from non-white and LGBTQ+ authors.

\section{Finding the Red Thread}

Overall, I could not see the logic of how various themes and concepts were organised, nor did I always understand why certain readings were assigned to specific lectures. Part of my discomfort also came from the examples which filled the reading lists and lecture slides: my colleagues who originally designed the course had very different research foci to my own, and it was difficult for me to feel like an expert when teaching from their material.

The first step in my process was to go through the lecture slides, notes and reading list, and create two lists: (1) main themes and theoretical concepts (2) empirical examples. For the former - themes and concepts - I also asked students on the last day of class in 2021 what they thought the main themes were. The main conceptual themes were then organised into primary and secondary themes.

For instance, a hypothetical empirical example could be found in a reading or slide about an ethnographic study of health tracking devices which, in turn, might be analysed or described in terms of responsibility. In this case, the concept of responsibility related to neoliberal reforms in the healthcare system, which shift responsibility from the health system and society to the individual. The empirical example - bealth tracking devices - is used to discuss a secondary theme - responsibility - which is a manifestation of a primary theme - neoliberalism in healthcare.

I then re-organized the themes, sub-themes and empirical examples so that the red thread became apparent. I then turned to individual lectures, to find different ways of organising the lectures in line with the primary and secondary themes. As part of this I deleted or combined some lectures where there was overlap and added others. For instance, and in light of themes discussed above, I added lectures on "ethnographic methods" and on "colonial bodies," with the latter examining the construction and exotification of "the other" and the extractive and exploitive nature of colonial practices.

I then reviewed the list of theoretical concepts and examples, looking for ways to respond to current conversations about power and privilege. As I discuss in the sections that follow, this included assigning literature from a more diverse group of authors and using examples from settings outside of Sweden and Europe. It also included questioning some of the main theoretical concepts used in ethnology and anthropology. 


\section{The Syllabus and Lectures}

In the Swedish higher education context, a syllabus is a broad overview of the course with a short summary and list of Intended Learning Outcomes (ILOs), which are required. It also includes 1-2 sentences on the course setup and a brief description of the assessment. The syllabus is designed to be relatively broad and genetic, because changing it is administratively difficult. What North American audiences think of a syllabus - with a summary of individual lectures and readings - is much more comprehensive than the typical Swedish syllabus. In Sweden, the reading list is a separate document which goes through a related, but separate approval process by a departmental committee. The broadness of the Swedish syllabus gives teachers significant room for manoeuvre in the implementation of the course.

There was relatively little that needed to be updated in the syllabus text, which reflects that the basic contents and perspective of the course were good. One of my previous colleagues was a disability studies scholar and "disability" focusses on the syllabus. Unfortunately, I had to remove this text because it is not my area of research and I could not promise to cover disability to the extent that its inclusion on the syllabus suggested. I did, however, make sure to highlight examples from disability studies in the lectures and on the reading list.

Once the main themes and the red thread were identified, and the overall ILOs finalised, I drafted a North American-style' syllabus, which included a summary of the lectures and assigned readings. In this document I also added notes on why certain readings were included, in part as a reminder to myself? The document was also intended for current and future lecturers and course convenors. That is, it explains the logic and rationale behind the different sessions. To this end, I was careful with how I used my research background in the course revision. I decided to largely exclude my own research from the reading list. I also designed my new lectures to be somewhat generic, but I drew on my own research for specific case studies. The idea was that future lectures could use the same lecture outlines and, hopefully, slot in their own research in the place of mine.

This process helped me to structure the course, to devise ILOs for individual lectures and to see the logical progression of topics or, the red thread. As a caveat, I am wary of the neoliberal misuse of ILOs (see Mihailova 2014; Loughlin et al 2021). However, I also find them helpful in organising and structuring individual lectures, in addition to the course at large.

\section{The Reading List}

There were two main changes to the reading list. Practically, some of the literature was out-of-date or difficult to find. In Sweden, in contrast to much of North America, students are not necessarily expected to purchase textbooks or course books (although this differs by discipline). Unfortunately, the library only had 1-2 copies of many assigned books, of which some were out-of-print. At other times, Byzantine rules and agreements with publishers meant it was impossible to order additional copies. In other cases - and returning to the red thread - I did not understand why a certain reading had been added to the reading list and assigned to a specific lecture. I was concerned that all of these barriers would prevent students from engaging with and enjoying the readings, not least because I did not enjoy most of the reading list!

The second task was to address the various movements which question power and legitimacy in the disciplinary canon. In its instructions for authors, Medical Anthropology Quarterly (MAQ) cites American author Toni Morrison: "canon building is empire building." The editors go on to describe "citation":

as a political, as well as a scholarly, practice. In light of this, and as part of a commitment to anti-racist and anticolonial scholarship, we expect authors to be mindful of whose work they choose to cite, and therefore recirculate, whose work they choose not to, and what forms of racialized and gendered inequity they may reproduce or challenge through those choices (MAQ, n.d.)

While MAQ's point here is citation in academic articles, the lesson is applicable to university readings lists. Because the course's starting point is Sweden and other Nordic healthcare systems and society, a relative amount of ethnocentrism is appropriate. In fact, pushing back against dominant, often Anglo-American, theories and literature and assigning Swedish-language research in and of itself is somewhat of a radical move.

That said, there are myriad ways in which Nordic anthropology and ethnology courses need to be decolonialized and amended (Diallo and Friborg 2021). Practically, the reading list certainly needed to take into account the 
experiences of indigenous peoples, and various ethnic, religious, sexual and other minority groups in Nordic settings. The course materials had already included literature about disability and there was an entire lecture on forced sterilizations in Sweden, of which people with intellectual disabilities, trans-people and minorities such as the Roma were disproportionally affected. However, there was still room for improvement, not least by also adding other minority perspectives and examples from Sápmi and Kalaallit Nunaat.

A wider move included how we addressed some of the dominant theories around power, risk and health, most of which come from white European men, such as Michel Foucault. This did not mean unassigning the literature, but rather adding other perspectives on the course themes, as well as literature critical of the 'traditional' canon. For example, rather than teaching Foucault's concept of governmentality as truth, there was a need to debate its strengths, weaknesses and applicability to other contexts.

\section{Conclusions}

Most lecturers have been in the position of taking over a course from colleagues, often at short notice. But they do not always have the time and resources to implement changes. Similarly, teaching is rarely reimbursed in relationship to the hours spent preparing lectures. I was supported by my department and division to make significant changes to the course. That is, I was literally paid to take the time to reflect on teaching practice and course the design; this is rarely the case in the neoliberal university.

However, courses need regular updating. This can be for practical reasons, as readings or slides become outdated. Updating a course also relates to the role of a university in society. From its inception, the course focussed on norm critique, particularly gender. But it needed to be adjusted to address other social movements, including calls for decolonialising classrooms, addressing sexual violence and racism. These changes improve student learning by creating a more inclusive space; it makes the statement that non-white, non-cis and nonheterosexual students belong in the university and in research.

In conclusion, by revising the course to find its 'red threads' and changing some of the theoretical perspectives and empirical examples to better reflect my research expertise, I feel much more comfortable with the course material, including the literature, lectures and activities. I also felt more empowered to question some of the traditional ethnological and anthropological canon, instead of simply teaching it as 'truth.' This will translate into a more confident and enthusiastic presence in the classroom which, in turn, will contribute to a better environment for critical discussions about power and health.

\section{Acknowledgements}

I would like to thank Emma Eleonorasdotter, Anna Tzanaki and Alexander Hedlund for comments on the manuscript.

\section{Disclosure statement}

No potential conflict of interest was reported by the author.

\section{References}

Abraham, G.Y. (2017) The neoliberal New Public Management influence on the Swedish Higher Education. KAPET. Karlstads universitets Pedagogiska Tidskrift. 13(1), 45-58

Barnett-Naghshineh, O. \& Pattabu, A. (2021) Decolonizing Anthropology: Race, Emotions and Pedagogies in the European Classroom. Teaching Anthropology. 10(4), 1-16

Cheang, S. and Suterwalla, S.(2020) Decolonizing the Curriculum? Transformation, Emotion and Positionality in teaching. Fashion Theory - Journal of Dress Body and Culture. 24(6), 879-900.

Diallo, O-K. M. \& Friborg, N.M. (2021). Subverting the white cis gaze: Toward a pedagogy of discomfort, accountability and care in the anthropology classroom. Teaching Anthropology. 10(4), 17-35 
Elmgren, M. \& Henriksson, A-S. (2018) Academic Teaching. 2nd Edition. Lund: Studentliteratur.

Krause-Jensen, J. \& and Garsten, C. (2014). Neoliberal turns in higher education. Learning and Teaching. 7(3), 1-13.

Loughlin, C., Lygo-Baker, S. \& Lindberg-Sand, A. (2021) Reclaiming constructive alignment. European Journal of Higher Education. 11(2), 119-136.

McGranahan, C. (2014) What is Ethnography? Teaching Ethnographic Sensibilities without Fieldwork. Teaching Anthropology. 4, 23-36

Posecznick, A. (2014) On theorising and humanising academic complicity in the neoliberal university. Learning and teaching. 7(1), 1-11

Primiano, S. J., Krishnan, A., \& Sangaramoorthy, T. (2020) Plagues, Pathogens, and Pedagogical Decolonization: Reflecting on the Design of a Decolonized Pandemic Syllabus. Teaching and Learning Anthropology Journal 3 (2), 47-60.

MAQ. Information for Authors. Medical Anthropology Quarterly https://medanthroquarterly.org/information-for-authors/

Mihailova, P. (2014). 'A place where open minds meet': The constraints of alignment and the effects of compulsory teacher training on teaching and learning in higher education. Learning and Teaching 7(3), 14-45.

Montesi, L. \& and Johansson, M.S.J (2021) Dog Bites and Gastrointestinal Disorders: Our Everyday Bodies in Teaching Anthropology and Fieldwork Preparation. Teaching Anthropology. 10(3), 59-69

Tentomas, L. (2021) An Anthropological Journey to The Field of Disability: Teaching and Research by a Disabled Anthropologist in Greece. Teaching Anthropology. 10(2):24-33

Torres, M. G. and Shandy, D. (2019) Transforming Teaching Towards Empowered Learning: What \#MeToo Taught Us About Anthropology. Teaching and Learning Antbropology Journal. 2(2). 62-71

Tuck, E., \& Yang, K. W. (2012) Decolonization is not a metaphor. Decolonization: Indigeneity, Education, \& Society. 1(1), 1-40.

Stefanelli, A.(2017) The Afterlife of Anthropological Teaching. Teaching and Learning. 7(1). 4-14.

Zembylas, M. (2018) Reinventing Critical Pedagogy as Decolonizing Pedagogy: The Education of Empathy. Review of Education, Pedagogy, and Cultural Studies 40 (5), 404-21. 


\section{Appendix 1: Taking Over and Revising a Course}

Congratulations - you are now the course convenor of an existing course. What do you do next?

\section{Assess what, if anything, needs to change about the course}

1. What works well about the course? If possible, discuss with previous lecturers and/or review student evaluations.

2. Can you - as the lecturer - easily identify the 'red thread' of the course? That is, can you identify the narrative coherence in the course material and structure?

3. Do you - as the lecturer - understand why individual topics are covered? Do you understand why specific readings are on the reading list and how they relate to the lectures? Do you understand how the course ideas and themes progress over the term?

4. Is the material up to date? Is it still in print? Does it need to be supplemented or should certain readings be taken off the list? Is there new or emerging research to discuss? Does the material reflect current societal issues?

5. Are the course materials and sessions sensitive to disciplinary considerations?

6. How can your own research strengths and interest be incorporated into the course - without making the course too dependent on you?

\section{Making and Implementing Changes}

1. Make a list of key themes, concepts and empirical examples in the course material. Do these need to be re-arranged, combined and/or separated?

2. What changes do you want to make? What is the rationale behind the changes? What deficits are you trying to address?

3. How will the changes contribute to student learning?

4. How will the changes contribute to your classroom experience?

\section{Evaluating Changes}

1. Do you feel that your changes have had the intended outcomes?

2. Are the intended outcomes reflected in student learning? This can include, but is not limited to, formal or informal course evaluations. It may also be reflected in the content of exam answers.

3. Are the students able to clearly identify the 'red thread' in the course?

\section{Documenting Changes and Course Material}

1. How easy would it be for someone to take over the course from you?

2. Is the course too dependent on the research interests and strengths of one or two people, or is it flexible?

3. Is there an easy-to-read document in which your changes are clearly described and their rational explained? 